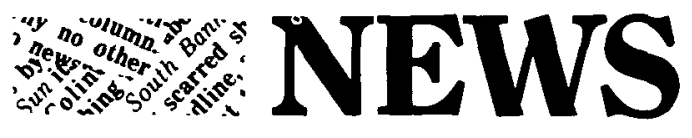

\section{New foods, new names}

Recent reports indicate that some overlooked Inca foods are now making their appearance in many parts of the world, with the possibility of becoming as well known as earlier South American exports that are now familiar in the home and the street, such as potato, tobacco and coca:

'Half a millennium ago in the Andes, on the eve of the Spanish conquest, the Incas had created an agricultural wonderland. On irrigated mountain terraces along the spine of South America, they cultivated an estimated 70 species of crops, almost as many as did the farmers of Europe and Asia combined. And what crops: white, yellow and purple roots that taste like a blend of celery, cabbage and roast chestnuts. Beans that pop like popcorn. Cereal grains containing twice the protein of wheat, rice or corn' (William K. Stevens, International Herald Tribune, 2 Nov 89).

'They used to be found only in places like the dim, narrow Sopacachi market in La Paz, stuffed in gunnysacks nearly hidden among the woven hoop skirts of the bowler-hatted Andean cholas who trek down from Bolivia's high plains to the capital with their wares. There the cholas purvey a dazzling array of exotic fruits, grains and vegetables' (John Elson and Laura Lopez, 'Anyone for Cherimoyas?', Time, Apr 90).

Names and foods to look for include:

aji a pepper that out-chillis the chilli and is already being used to give added zest to Mexican and Sechuan dishes.

arracacha 'a smooth-skinned root that looks somewhat like a white carrot, it delicately combines the tastes of celery, cabbage and roast chestnuts' (Stevens). It can be baked, boiled, fried, or added to stews.

cherimoya (also known as 'the pearl of the Andes') a green-skinned fruit with creamy, custard-like white flesh 'that tastes like a blend of papaya, pineapple and banana' (Stevens). It is already being farmed in California, Mexico, and New Zealand. 'When ripe, the fruit, which can be as small

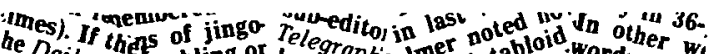
he $D_{a i l y}$ Stej abling or longraphalaer tabloid. words will m-equally, "pospapel sug one. New work Rudoll subeditor,

as a baseball or as big as a cantaloupe, looks like an abused avocado' (Elson and Lopez). They currently cost about $\$ 10$ a pound in New York City.

oca a tuber 'like a stubby wrinkled carrot' (Stevens). Ocas have been described as 'potatoes that don't need sour cream'.

naranjilla ('little orange' in Spanish, also known as 'the golden fruit of the Andes') an orange-yellow fruit like a tomato, with green pulp, with juice that some prefer to orange juice.

nuñas (also known as 'popping beans') When they are dropped into hot oil, nuñas evidently burst out of their seed coatings and open like small butterflies. Stevens predicts that they could become a nutritious snack, high in protein and low in starch.

pepino dulce 'A yellowish, egg-shaped melon with purple stripes and a slightly cloying taste that resembles mild honey' (Elson and Lopez). It is a cousin of the tomato and makes a good appetizer or dessert, and the pulp can be frozen, jellied, bottled, or canned. It currently costs about $\$ 8$ a pound and is becoming popular in Japan.

quinoa 'a superstar grain . . . fairly bursting with fiber, protein, iron and amino acids' (Elson and Lopez). It is apparently already successfully grown in Canada, Britain and Scandinavia. It has a mild taste rather like wild rice and can be made into flour and pasta.

ulluco a root with a nutty taste, a shiny skin, and yellow, pink, red, purple, and candy stripes, so exotic that it looks like a plastic fake.

\section{CD-Robert: French dictionary online}

After several months of closeted silence, Dictionnaires Le Robert has finally brought out a CD-ROM version of its original nine-volume Grand Robert De La Langue Française.

Called Le Robert Electronique, this mas- 
sive lexibase consists of 80,000 records on lexical forms including semantic, phonetic and etymological info, together with historical citations plus synonyms, homonyms and derived words.

The navigation software, developed by Franco-Belgian CD-ROM specialist Bureau van Dijk, allows you to check the information in these records in many combinations, for instance grouping networks of associations between words on the screen.

You can call up the citations by multiple criteria, and you can access the dictionary for spellchecking direct from your wordprocessor - as well as dumping any lexicographical material you need from the dictionary into a working file.

Le Robert Electronique runs on CD-ROM drives linked to a PC XT or AT with $512 \mathrm{~Kb}$ of memory. Price: FF7,709 (US\$1000). Dictionnaires Le Robert, 107 avenue Parmentier, 75011 Paris, France.

(Taken from the LIS Press Bulletin No. 6, 1990:

PO Box 5477, 1007 AL Amsterdam, The

Netherlands.)

\section{Books in a cold climate}

Cold storage may be the answer to the problems of paper conservation. A Swedish monastery at Skoklosters Slott has demonstrated the advantages of freezing books in order to preserve them - the library is housed in an unheated room with open grilles where winter temperatures can fall to well below $-10^{\circ} \mathrm{C}$. Books (though possibly not monks) have survived remarkably well for over 300 years. Storage at low temperatures slows the rate at which paper is attacked by acids, and also reduces damage to inks and bindings. Photographs and microfilm, which are even less durable, are found also to last longer in cold storage.

At the forefront of freezing techniques are the East German State Film Archive which keeps much of its material at $-10^{\circ} \mathrm{C}$, and the National Library of Australia in Canberra where a new facility has recently been completed to store over three kilometres of lowuse material at $8^{\circ} \mathrm{C}$. Most of the original material in the cold store has already been microfilmed, and the originals are therefore rarely required. Master copies of the microfilms are also held in cold storage, whilst a working film is kept at room temperature.

According to Marie Jackson of the National Preservation Office, no British library has as yet opted for cold storage. Problems only occur when stored material is required by a reader - there is a 24 -hour delay whilst the item is acclimatised from $8^{\circ} \mathrm{C}$ to $16^{\circ} \mathrm{C}$.

(From the NIDS Newsletter, Chadwyck-Healey Ltd, Cambridge CB2 INR, UK.)

\section{From the NCTE Committee on Public Doublespeak: a press release (reprinted verbatim)}

To help the American public develop a critical ear for public statements, committee members and other language specialists have collaborated on a book probing the efforts at manipulation everyone faces daily in this information age. Beyond Nineteen EightyFour: Doublespeak in a Post-Orwellian Age is edited by Doublespeak Committee Chair William Lutz of Rutgers University, Camden, New Jersey, and published by NCTE.

The authors, most of whom teach English or linguistics in colleges and universities, probe the tactics of persuaders from many sectors of society. Lutz leads off by highlighting the methods they use. Euphemisms, specialized jargon, bureaucratese, and inflated language come in handy, he points out, if you want to shape information to your advantage and divert attention from unpleasant implications of what you propose or advocate. The subliminal message, he says, tends to be 'Don't worry' - about a neutron bomb because it's just an 'enhanced radiation device', or about acid rain because it's only 'poorly buffered precipitation'.

This potential for harm to society, Lutz says, is why many teachers of English today think that 'there is more to using language, and to the teaching of English, than making subjects and verbs agree'. All language users, he insists, 'should be concerned whether statements and facts agree', and whether, in author George Orwell's words, language is being 'designed to make lies sound truthful'. 
Among the eighteen contributors to Beyond Nineteen Eighty-Four are such well-known writers on language as Walker Gibson, Frank J. D'Angelo, Richard Ohmann, Don L. F. Nilsen, Edward $M$. White, and Charles Weingartner. Weingartner points out that because all language comes from people speaking or writing, it is never neutral. He inquires into how we know what we know about today's world and observes that under the guise of presenting information, today's message-makers also offer misinformation, disinformation, even anti-information or semi-information. Weingartner probes the limitations of TV as an information source and of trivia-fed viewers' ability to focus on complex issues. He points out that people tend to 'know the truth' through their emotions.

Other contributors explore the kinds and extent of doublespeak in use today. Donald Lazere analyzes disinformation. Ohmann reflects on the semantics of foreign policy discourse. Dan F. Hahn probes the techniques politicians use to say nothing, and D'Angelo examines jargon. Scott Buehler looks at ways doublespeak is used by promoters of technology.
Nilsen discusses the linguistic processes advertisers use to give an ad multiple meanings, while Roy Fox examines 'sensationspeak', the language of the grocery store tabloids. Julia Penelope discusses doublespeak in higher education, and Charles Suhor inquires into the language 'pop grammarians' use to establish themselves as arbiters of correctness.

Edward $M$. White highlights another danger, 'singlespeak': a literal-minded attitude on the part of some segments of the public today, who insist that 'reality is simple and knowable and that language should reflect that simplicity'. Believers in singlespeak, White says, 'appeal to the solid virtues of the Frontier' in rejecting complexity. They see no use for metaphor or irony, and blindly trust that all problems have simple solutions.

(Beyond Nineteen Eighty-Four: Doublespeak in a Post-Orwellian Age, edited by William Lutz. 224 pages, paperbound. Price: \$15.95; NCTE members, \$12.95. ISBN: 0-8141-0285-9. LC: 89 12707. Audience: general readers interested in language issues, teachers of English and writing at all levels. Available from NCTE, 1111 Kenyon Road, Urbana, Illinois 61801. Stock No. 028590015.)

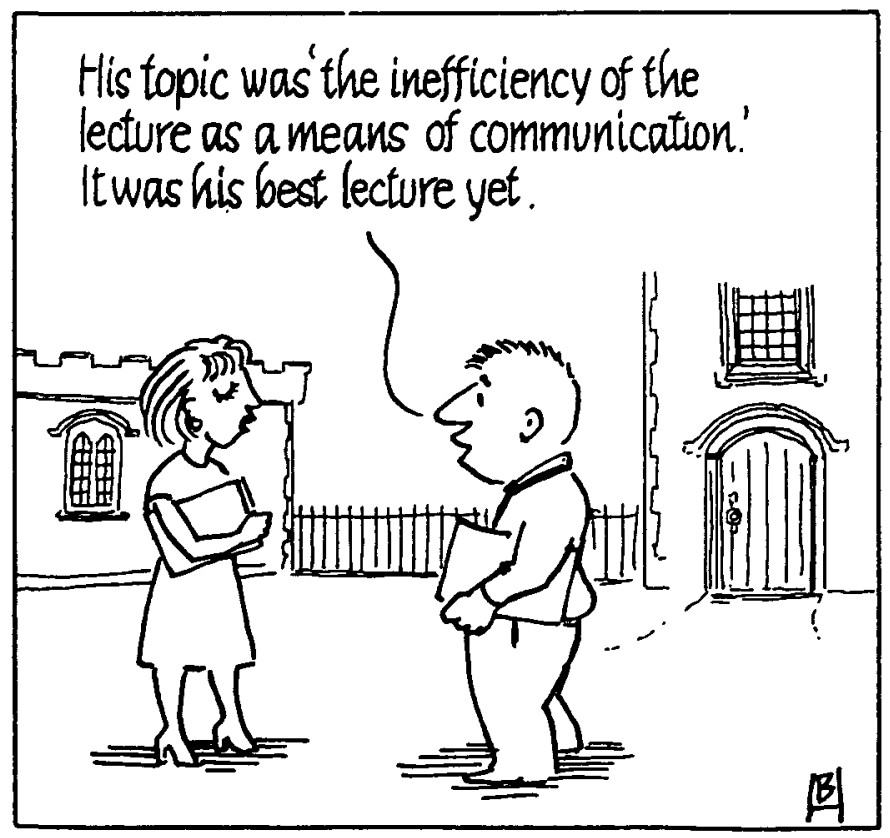

